\title{
Business Climate, Political Risk and FDI in Developing Countries: Evidence from Panel Data
}

\author{
Hadjila KRIFA-SCHNEIDER (corresponding author) \\ Laboratory EQUIPPE - Lille Universities \\ Faculty of Economics and Social Sciences \\ Lille University of sciences and technologies, 59655 Villeneuve d'Ascq \\ E-mail: Hadjila.Krifa@ifresi.univ-lille1.fr
}

Iuliana MATEI

Associate Researcher - CES and CNRS (UMR 8059)

University of Paris 1- Pantheon Sorbonne

E-mail: iuliana.matei@malix.uni-paris1.fr

\begin{abstract}
The literature on economic development views institutions as a crucial location advantage of host countries aiming to attract foreign investors. The purpose of the paper is to explore empirically the linkages among political risk, business climate and foreign direct investment inflows and to provide better supported results concerning these linkages. For this purpose, we exploit two panel models: a fixed effect model and a dynamic panel model (the Arellano-Bond GMM estimator) for a data sample of 33 developing and transition countries covering the period 1996-2008 and we identify indicators that count the most for the foreign direct investors. These methodological insights lead to the following main results. Firstly, we show that reduced levels of political risk are associated with an increase in FDI inflows. Secondly, the business operation conditions appear as an important determinant of FDI flows, our results indicating that favourable business conditions participate to an increase of the FDI.
\end{abstract}

Keywords: Foreign Direct Investment, Gravity model, Institutions, Developing countries

JEL Classification: F21, F23, R3

\section{Introduction}

FDI is supposed an engine of the growth for countries, providing a package of financial capital, technology, managerial skills, jobs opportunities, information, good and services that can make an economy more competitive in the world market place. Especially for developing and transition countries that face liquidity constraints, this source of funding is considered as the best way to capture less volatile capital flows and attract MNEs that could boost their productivity. Although, the empirical literature does not clearly conclude about the impact of FDI on growth rate (for a survey see Busse and Groizard, 2008; Beudegesdik and al. 2008), all countries - and especially developing and transition countries - compete each other to capture greater amounts of FDI inflows. This competition could explain why the FDI flows grew significantly since the 1990s but not why they don't' succeed equally.

The traditional theory on the FDI gives us a first explanation. According to the "OLI paradigm" (Dunning 1988), which is one of a complete and often used framework, a firm decide to invest abroad to exploit its ownership (O), location (L) and internalization (I) advantages. The ownership advantages arise from the firm's of ownership of intangible assets, such as technology, managerial skills, patent, commercial network, reputation.... These assets will give it a market power to balance the disadvantages of the abroad production. The location advantages stem from the assets that the host market supply, such as abundant natural resources, large market size, cheap factor of production and infrastructure development. The internalization advantages focuses on the firm's preferences to produce abroad through wholly owned subsidiaries and joint ventures rather than licensing or subcontracting for example. The aim is to minimize the firm's transaction costs.

While both ownership and internalization advantages are specific firm motives, the concept of location advantage capture properties of host country that make it attractive to potential FDI investors. Two types of FDI could be distinguished: horizontal or vertical (classification by Markusen, 1995; Markusen and Venables, 1999). Horizontal FDI is a market-seeking investment the firm is supplying the domestic market, through an affiliate, with similar products than it offers on its home market. The objectives are to gain in trade costs and to improve strategic advantages in the rivalry with other local competitors. The foreign firm appears for example as an inside producer 
close to the consumers, or can learning about their taste and behaviours. Contrary, vertical FDI is resource-seeking based on relative endowments and aims to minimize production costs, typically by utilizing a cheap labour force, and is attracted by factor cost differentials and repelled by trade costs. In the context of a globally economy, the most general model in Markusen (2002), called the knowledge-capital model, combines both vertical and horizontal multinational behaviour.

Although this previous literature has, in a large extent, characterized the main factors, which determine the flows of FDI and the location behaviour of the MNE's, it seems insufficient to explain the unequal international distribution of these flows between countries. Other FDI determinants received much attention recently in the context of emerging countries. Among these determinants, the quality of institutions is viewed as a crucial location advantage, especially for these countries (Barrell and Pain, 1999; Bevan, Estrin S. and Meyer, 2004; Bénassy-Quéré, Coupet and Mayer 2007; Jinjarak, 2007; Busse and Hefeker, 2007; Kostevc, Redek and Susjan, 2007; Demekas, Horvath, Ribakova and Wu, 2007; Demirbag M., Glaister, and Tatoglu, 2007; Du and Tao, 2008; Ali, Fiess and Mac Donald, 2010). Good institutions, which secure property rights, guarantee the political stability and weaken the corruption, promote a good investment climate.

As the researchers above cited, we suppose also that good institutions play a crucial role to attract foreign direct investors. Thus, rather than focusing on a broad range of traditional determinants of FDI, we focus on the relation between business climate, political risk and FDI. The paper investigates empirically this for a set of 33 developing and transition countries over 1996-2008 and also identifies indicators that count the most for the foreign direct investors.

This paper has a value added in empirical and methodological point of views. Indeed, Singh and Jung (1996) have analysed the impact of the political risk and business climate on FDI by using an aggregate index for these two variables. Busse and Hefeker (2007) studied the impact of 12 individual index of political risk on FDI. In this paper, we provide better empirical results concerning these institutional variables by considering two models: a panel model and a dynamic panel model. These methodological insights will lead to the following main results. Firstly, we show that a reduced level of political risk is associated with an increase in FDI inflows. Secondly, the business operation conditions appear as an important determinant of FDI flows, our results indicating that favourable business conditions increase the FDI flows.

The paper will be organized as follows. After this introduction highlighting the key features of FDI literature, the goal and the main results of the paper, section 2 offers a brief survey of the literature and precise our hypothesis. Section 3 presents the methodology. Section 4 specify the econometric model and give the empirical results. Concluding remarks are reported in section 5 .

\section{Brief survey of the literature and hypothesis}

The installation of an adequate institutional framework (property rights, convertibility of the currency, laws on the bankruptcy of the companies and monitoring of the markets...) and the quality of the reforms favourable to the market economy (liberalization of the prices, privatisation of the public enterprises and encouragement of the private sector, reorganization of the financial system, liberalization of capital account...) represent key aspects recently analysed in the literature on economic development. These aspects were, in particular, associated with a greater prosperity and now start to occupy a central place in the formation of the fixed assets in the emerging economies. Better institutions should encourage more FDI inflows and consequently, contribute to economic growth and the development. The factors, which concern the specific degree of difficulty of implementation, are generally captured by an analysis in terms of country-risk or in terms of business climate.

The term of country risk is usually related with cross border investments (Nordal, 2001; Luo, 2009 for a survey). Indeed, a most part of investments taking place across international borders involves additional risks not present in domestic investments. These additional risks arising from a diversity of national differences in economic structures, policies, social-political institutions, geography and currencies are captured by the country risk. Hence, the term country risk identifies situations in that potential for these additional risks deteriorate the business climate and diminishes the expected return of a cross-border investment. The literature highlights three big components of country risk: the economic risks, the financial risks and the political risks. Among these three components, political risk is more critical in importance and more multifaceted in impact than financial or economic risks. It is the reason why our first task is to include the political risk and some of its components that are found to be significant in the empirical studies in the evaluation of FDI.

Hypothesis 1: Does political risk has an important influence on FDI?

By political risk we understand a situation in which the political and the social factors may affect a country's ability and willingness to respect its financial obligations. This definition requires both macro and microelements coming 
from host-country and the non-host country environment. It reflects the degree of uncertainty associated with different decisions taken by the political institutions such as governmental and legislative agencies (Luo, 2009). For example, Busse and Hefeker (2007) investigate the linkages among political risk, institutions and FDI inflows for a data sample of 83 developing countries covering 1984-2003. Using the Arellano-Bond GMM dynamic estimator, they found that many sub-components of political risk (government stability, internal and external conflict, corruption and ethnic tensions, law and order, democratic accountability of government and quality of bureaucracy) impact FDI inflows. Henisz (2002) shows that multinationals are confronted with an increasing threat of expropriation if political risk rises in the host country. Their results illustrate that the impact of political risk depends on the strategic behaviour of the multinational as a partner with host firms having strategic interactions with the host-government. In the same line, Nordal (2001) considers that the political risk may constitute a huge part of country-level risk when foreign investors locate in emerging countries. Jun and Singh (1996) study the impact of the political risk on the FDI inflows for 31 developing countries. Their results stress that the aggregate index of the political risk is significant, countries characterized by a high political risk attracting less FDI.

Hypothesis 2: Does the perception of favourable business operating climate positively affect FDI inflows?

Another factor that plays a key role in attracting FDI is the business climate. Even if in the literature we find a consensus about the importance of this variable, there is still not unanimity about the size of its impact. Fung and al. (2005) show that better business climate, which they call "soft" infrastructure is more important in attracting FDI than hard infrastructure (roads). On the other hand, the degree of the impact differs according to the countries that are studied: the impact is more important in the case of flows coming from United States and Japan and it has a smaller magnitude for flows coming from Hong Kong and Taiwan. Using firm-level data across 77 developing countries, Kinda (2010) shows that constraints related to business climate obstruct FDI. More precisely, the author highlights that physical infrastructure problems, financing constraints and institutional problems depress FDI. Using also a similar methodology for eight Latin American and Asian Countries, Dollar, Hallward-Driemeir and Mengistate (2006) analyse the impact of investment climate and FDI probability. They conclude that a better investment climate encourages FDI. Fabry and Zeghini (2002) and Krifa and Baudouin (2008) show, in the special case of Russia, that a bad investment climate explains why this country is less attractive for FDI.

\section{Methodology}

\subsection{Sources of Data}

The data panel contains observations from 33 developing and transition countries and cover the period from 1996 to 2008. We included developing and transition countries for which data on all variables in the estimations are available. Table 1 presents a summary of our variables and their sources of data.

[Insert table 1 here]

\subsection{Variables and measures}

\section{1) Dependent variable}

The dependent variable is the natural logarithm of FDI inflows in percentage of GDP for country $i$ in year $t$. Data on FDI inflows come from World Bank database (2010). But, the FDI inflows refer to foreign investments for which multinational corporations own $10 \%$ or more (such as China) of the local firm. The FDI data refer only to a part of resources invested by the multinationals in the host country. The investments financed trough debt or equity are not taken into account, fact that may underestimate the size of investment done by multinationals abroad (see Busse and Hefeker, 2007 for a discussion on this).

\section{2) Control variables}

The vector of independent variables contains two types of variables: the control variables and the hypothesis variables. Our benchmark specification contains the next control variables:

- Gross national income per capita (GNI in PPP per capita) to control for the market size

- Growth rate of GDP in \% (GROWTH) to control the market growth and the market potential

- Ratio of exports and imports to GDP (TRADE) to capture the openness of trade

- The GDP deflator (INFLATION) as a proxy of macroeconomic policy inadequacies

The first two variables are expected to be positively associated with FDI inflows while the variable "inflation" negatively associated with FDI. Concerning the impact of the variable "trade" on FDI inflows, the sign that we expect can be positive or negative. 


\section{3) Hypothesis variables}

The independent variables of interest are represented by the hypothesis variables. Following the discussion of the previous section, we include two hypothesis variables. The first one is the business climate and the second one is the political risk (as an important component of country-risk). Both variables come from the Worldwide Governance Indicators for 2009 and are available since 1996. These variables are assessed on a scale from 0 to 1, with higher values indicating lower political risk and favourable business climate while lower values refereeing to higher political risk and, respectively, bad business climate. Consequently, we expect that low political risk and attractive business climate be positively related with FDI inflows.

Jung and Singh (1996) were the first authors that empirically studied the influence of the political risk and the business climate on FDI inflows using aggregate indices. From this point of view, our empirical results are novel and more accurate in the sense that we provide two empirical models: fixed-effect model and a dynamic panel data model (Arellano-Bond GMM estimator).

\section{4) Robustness Checks}

To test the robustness of our benchmark models, we include progressively some control variables such as unit labour costs, hard infrastructure, public expenditure and real exchange rate. As concerns labour unit costs, the results highlighted in the literature are contradictory: Schneider and Frey (1985) and Jung and Singh (1996) find that FDI are negatively affected by labour costs while Lipsey (1999) finds a positive impact or no significant importance on FDI. Hard infrastructure has a positive impact on FDI and we expect that it is less significant than "soft infrastructure" captured by the variable "business conditions" (Fung and al., 2005). Public expenditure refers to expenditures in public infrastructure and we expect that affect positively the FDI inflows. As Jung and Singh (1996), we include the real exchange rate to control for exchange rate risk. Concerning this aspect, Lucas (1993) considers that the exchange rate "may have a residual role with respect to the exchange rate risk, for example, in determining the value of repatriated profits or in threatening restrictions on such remittances" (p. 393).

\subsection{Empirical specification}

In this paper, we use a simple equation often used in FDI location studies:

$$
\mathrm{FDI}_{\mathrm{it}}=\alpha \mathrm{X}_{\mathrm{it}}+\beta \mathrm{F}_{\mathrm{it}}+\mathrm{u}_{\mathrm{i}}+\theta_{\mathrm{t}}+\varepsilon_{\mathrm{it}}
$$

where $\mathrm{FDI}_{\mathrm{it}}$ is the FDI inflows in \% of GDP in country $i$ at the time $t, \mathrm{X}$ is a vector of control variables, $\mathrm{F}$ is a vector of our hypothesis variables (mainly the political risk and the business climate), $u$ is a country fixed effect (for a fixed-effects model), $\theta$ is a time fixed effect, $\varepsilon$ is the error term, and $i$ and $t$ are, respectively, the country and time subscripts. We note that all variables are in logarithm. But, some of our variables are negative and consequently, their simple transformation in log is a little problematic. It is why, we employ a transformation used by Busse and Hefeker (2007) that permits to maintain the sign of each negative variable and to preserve the maximum number of observations in the panel:

$$
\mathrm{y}=\ln \left(\mathrm{x}+\sqrt{\left(\mathrm{x}^{2}+1\right)}\right)
$$

where $\mathrm{y}$ is the new observation obtained after transforming the initial negative observation $\mathrm{x}$ (for growth, FDI per capita inflows and inflation).

The paper examines the linkages among business climate, political risk and the FDI inflows. We expect that the foreign investors favourably perceive countries with a reduced political risk and attractive business climate. Consequently, the FDI inflows will be positive influenced by high values of these factors. The equation (1) could be re-written as follows:

$$
\begin{aligned}
\operatorname{LnFDI}_{\mathrm{it}}=\alpha_{0}+\alpha_{1} \operatorname{lnGNI} \mathrm{CAP}_{\mathrm{it}}+\alpha_{2} \operatorname{lnGROWTH}_{\mathrm{it}}++\alpha_{3} \operatorname{lnOPENNESS}_{\mathrm{it}}+\alpha_{4} \operatorname{lnINFLATION}_{\mathrm{it}} \\
+\alpha_{5} \ln \mathrm{INST}_{\mathrm{it}}+\mathrm{e}_{\mathrm{it}}
\end{aligned}
$$

where $\alpha_{j}$ are the parameters to be estimated, FDI is the FDI in \% of GDP, GNI/CAP is the Gross National Income per capita (in current international PPP US dollars), GROWTH is the growth rate of GDP per capita in \%, OPENNESS is the ratio of exports and imports to GDP to control for openness, INFLATION is the GDP deflator and finally, INST gathers one of the two hypothesized variables: the political risk and the business climate.

All pooled models are estimated with ordinary least squares. To choose between fixed and random effects, we use the Hausman test (1978) that is an accepted way to run it. After running both models, we retain the fixed-effects models because it gives better p-values. A second econometric problem concerns the autocorrelations of the disturbances that can involve biased coefficients affecting the interpretation of our results. A way to solve this problem is to apply standard Durbin-Watson d statistic by testing autocorrelated errors. A third econometric problem 
is that the time-invariant country characteristics (fixed effects), such as geography and demographics, may be correlated with explanatory variables. The last econometric problem is that our panel data set has a short time dimension ( $\mathrm{T}=13$ years) and larger country dimension ( $\mathrm{N}=33$ countries). To solve these econometric aspects, we applied the Arellano-Bond (1991) difference GMM estimator that transforms the eq. (1) into the following form:

$$
\Delta \mathrm{FDI}_{\mathrm{it}}=\gamma_{1} \Delta \mathrm{FDI}_{\mathrm{i}, \mathrm{t}-\mathrm{1}}+\gamma_{2} \Delta \mathrm{X}_{\mathrm{it}}+\gamma_{3} \Delta \mathrm{F}_{\mathrm{it}}+\Delta \varepsilon_{\mathrm{it}}
$$

Or the equation (3) in the following form:

$$
\begin{aligned}
\Delta \operatorname{Ln~FDI~}_{\mathrm{it}}=\alpha_{0}+\alpha_{1} \Delta \operatorname{lnGNI} / \mathrm{CAP}_{\mathrm{it}} & +\alpha_{2} \Delta \operatorname{lnGROWTH}_{\mathrm{it}}++\alpha_{3} \Delta \operatorname{lnOPENNESS}_{\mathrm{it}} \\
& +\alpha_{4} \Delta \operatorname{lnINFLATION}_{\mathrm{it}}+\alpha_{5} \Delta \ln \mathrm{INST}_{\mathrm{it}}+\Delta \mathrm{e}_{\mathrm{it}} .
\end{aligned}
$$

As instruments for lagged difference of the endogenous variables, we employ the variable named distance computed as the natural $\log$ of the greater cycle between the centers of the selected country $i$ and the equator and the quality of EU member. It is worth noting that by transforming the regressors by first differencing the fixed country-specific effect is removed because it does not vary with time. Finally, the literature (for example, Holtz-Eakin, Newey and Rosen, 1988) argues that Arrelano-Bond (1991) estimator is usually indicated for small-T and large-N panels.

\section{Results}

\subsection{Regression results of the panel analysis}

We first present the results of the fixed-effect model from 1996 to 2008 and then, the results of the dynamic panel data. In these models, we do not include more than one institutional variable at a time because of their correlation (see correlation matrix in appendix B). We will start the presentation with the main variable of our interest: business climate that influences the political risk. So, political risk impacts the business climate: low levels of political risk imply better business conditions for foreign investors. Next, we will present the robustness checks of each panel model.

\section{1) Business climate and FDI}

Table 2 provides the results of analysing the impact of the business climate on FDI. The variable "business climate" has a positive impact on the FDI inflows. But, the coefficient of this variable is not significant in either panel models. The positive sign implies that favourable business climate involve high FDI inflows.

The only variables that appear significant at $1 \%$ or $5 \%$ level are the GNI per capita, the inflation and the trade openness. In summary, these results imply that FDI attracted to countries with good government track records as indicating by stable and high GNI per capita and trade openness, and with high quality business conditions as captured by the variable "business climate" even if the coefficient is not significant.

Among our control variables, only the coefficients of the variables "public expenditures" and the "political risk" are significant at $1 \%$ and respectively, $5 \%$ level. The variable "unit labour costs" is positively linked with FDI inflows but its coefficients are non-significant. It is worth noting that this result is in line with the findings of Lipsey (1999).

[Insert table 2 here]

\section{2) Political risk and FDI}

Table 3 provides the results of analysing the impact of the political risk on FDI using fixed effects models. The first column (1) shows the results of the benchmark specification, column (2) integrates the variable "political risk". Next columns test for the robustness of the results.

In our benchmark specification, all control variables have the expected sign (except for the variable "growth" whose coefficient is surprisingly negative). The variable "trade openness" is significant at $1 \%$ level and the variable "inflation" at 5\% level. The columns 3 to 7 give the results obtained when we add some control variables to check for the robustness of the model. As concerns the variable of our interest "political risk", the results show that it is significant at 5\% level and positively associated with FDI. Among our control variables, the coefficients of GNI/cap, public expenditure, trade openness, and inflation are significant at $1 \%, 5 \%$ or $10 \%$ level. The coefficient for unit labour cost has a positive sign that isn't significant. This result is in line with the findings of Lipsey (1999) that finds a positive impact or no significant importance on FDI. The variable "exchange rate" is positively associated with FDI but its coefficient is not significant while the variable "hard infrastructure" is negatively and non-significantly associated with FDI inflows. .

[Insert table 3 here]

\subsection{Regression results of the dynamic panel analysis}

This section presents the results of our estimations using the Arellano-Bond (1991) GMM estimator. Compared to 
the previous analysis, the GMM estimator does not use fixed effects because of its first differences. We illustrate first the results on the business climate and then those corresponding to the political risk.

\section{1) Business climate and FDI}

Table 4 summarizes the results of our estimations. As in the earlier section, the first column (1) and the second column (2) present the results of our benchmark models while the columns from (3) to (5) search for the robustness of the results. An in the previous case, we find a positive coefficient for the variable "business conditions". The dynamic model additionally shows that favourable business conditions represent a key determinant for FDI, the coefficient of this variable being generally significant at $5 \%$ level.

In all dynamic panel models, the lagged variable "FDI" appear significant at $1 \%$ level; foreign investors investing in countries that traditionally attract FDI. The variables: GNI/cap, trade openness, inflation, and public expenditure appear again significant in estimations and generally have the expected sign (except for inflation). Other variables such as growth, real exchange rate, hard infrastructure and political risk (which can be correlated with business climate) are not significant. Hence, compared with the fixed effects models, the relationship of FDI and business climate is a more robust one. In specification 4, the variables "inflation" and "growth" are not significant and the final variable has the expected sign. Overall, FDI inflows correlate positively and significantly with stable government's track record (GDI per capita and trade openness as complements) while business climate score matters.

[Insert table 4 here]

\section{2) Political risk and FDI}

Table 5 presents the results including the variable "political risk". As previously, the firstand the second columns show results of our benchmark model while the columns from (3) to (5) search for their robustness.

In these regressions, the results on the variable "political risk" are a little disappointing in the sense that this variable is not significant and does not have the positive sign as we expect. Among the control variables: the lagged FDI inflows, the GNI /cap, trade openness, inflation, public expenditure, unit labour costs and real exchange rate are significant. The variable "inflation" does not have the expected sign as well as the "hard infrastructure".

[Insert table 5 here]

\section{Conclusions}

The business climate change and the political risk represent defining issues of our time and their favourable levels offer huge opportunities for foreign investors. The aim of this paper was to analyse the linkages among business climate, political risk and foreign direct investments for a data sample of 33 developing countries over the period 1996-2008.

For this purpose, we used two main models: a fixed effect model and a dynamic panel model using the Arellano-Bond GMM estimator. Our main results could be summarized as follows. The fixed effect model highlights the importance of the political risk and the soundness of the government track record (the role of the trade openness and GNI per capita) while the business conditions do not significantly associated to FDI inflows. As concerns the dynamic panel model, the results are more convincing regarding the business climate in the sense that favourable business conditions are significantly and positively associated with FDI inflows. To put our results into perspective, the scale of FDI will depend on the progress made in delivering sound economic policies, good governance, socio-political stability and adequate infrastructure.

\section{References}

Ali F. A, Fiess N and MacDonald R. (2010). "Do institutions Matter for Foreign Direct Investment”, Open economic Rev, 21:201-219

Barrell R. and Pain N. (1999). "Domestic institutions, agglomerations and foreign direct investment in Europe", European Economic Review, Vol. 43, Issues 4-6, pp. 925-934.

Benassy-Quere, A., Coupet, M. and Mayer, T. (2007). "Institutional determinants of foreign direct investment", The World Economy, Vol. 30(5). 764-782.

Beugelsdijk, S., Smeets, R. and Zwinkels, R.C.J. (2008). "The impact of horizontal and vertical FDI on host's country economic growth", International Business Review, Vol. 17, 452-472.

Bevan A., Estrin S. and Meyer K. (2004). "Foreign investment location and institutional development in transition economies", International Business Review 13, p.43-64. 
Busse, M. and Hefeker C. (2007). "Political risk, institutions and foreign direct investment", European Journal of Political Economy 23, 397-415.

Busse M., and Groizard J.L. (2008). "Foreign Direct Investment, Regulations and Growth" The World Economy, Blackwell Publishing, vol. 31(7). 861-886.

Demekas, D. G., Horvath, B., Ribakova E. and Wu Y. (2007). "Foreign direct investment in European transition economies -The role of policies", Journal of Comparative Economics, 35, 369-386.

Demirbag M., Glaister, K.W and Tatoglu E. (2007). "Institutional and transaction cost influences on MNEs' Ownership Strategies of their Affiliates: Evidence from an Emerging Market”, Journal of World Business 42(2). 418-434.

Dollar, Hallward-Driemeir, and Mengistate. (2006). "Investment climate and international integration. World Development, 39(9). 1498-1516.

Du J., Lu Y., Tao Z. (2008). "Economic institutions and FDI location choice: evidence from US multinationals in China", Journal of Comparative Economics, 36, 412-429.

Dunning, J.H. (1988). “Explaining International Production”, Harper Collins Academic, London.

Egger, P., and Winnerb, H. (2005). "Evidence on corruption as an incentive for foreign direct investment", European Journal of Political Economy, Vol. 21(4). p. 932-952.

Fabry, N. and Zeghni, S. (2002). "Foreign direct investment in Russia: how the investment climate matters", Communist and Post-Communist Studies, Vol. 39, Issue 2, p. 201-219.

Fung, K.C. Garcia-Herrero, A., Iizaka H., Siu, A. (2005). "Hard or Soft? Institutional reforms and infrastructure spending as determinants of FDI in China", Japanese Economic Review, vol. 56, issue 4, 408-16.

Hausman J. A. (1978). "Specification Tests in Econometrics", Econometrica, vol. 46, issue 6, p. 1251-71.

Henisz, W. J. (2000). "The Institutional Environment for Economic Growth", Economics and Politics, Blackwell Publishing, vol. 12(1). 1-31, 03.

Holtz-Eakin, Douglas \& Newey, Whitney \& Rosen, Harvey S, (1988). "Estimating Vector Autoregressions with Panel Data," Econometrica, Econometric Society, vol. 56

Jun K. and Singh H. (1996). "The Determinants of foreign direct investment in developing countries", Transnational Corporations, Vol. 5, p. 67-105.

Kaufmann D., Kraay A. and Mastruzzi M. (2009). "Governance Matters VIII: Aggregate and individual Governance Indicators", Policy Research Working Paper 4978, World Bank.

Lipsey, R. E. (1999). "The location characteristics of US affiliates in Asia", NBER Working Paper No. 6876.

Lucas, R. (1993). "On the Determinants of Direct Foreign Investment: Evidence from East and Southeast Asia", World Development, Vol. 21 (3): 391-406.

Kinda T. (2010). "Investment climate and FDI in developing countries: Firm-Level Evidence". World development, Vol.38, No.4, p. 498-513.

Krifa-Schneider H et Bauduin N. (2008). "Dynamique et déterminants des investissements directs étranger en Russie ”. Innovations, cahiers d'économie de l'innovation, De Boeck, n²6, septembre.

Kostevc C., Redek T., and Susjjan A. (2007). Transition Studies Review, 14 (1): 40-54.

Luo Y. (2009). "Political risk and country risk in international business. Concepts and measures", chap 26, in Ed. Rugman, A.M., The Oxford Handbook of International Business. Second edition, Oxford University Press, p. 740-764.

Markusen, J.R. (1995). "The Boundaries of Multinational Enterprises and the Theory of International Trade", Journal of Economic Perspectives, No 9 (2).

Markusen, J.R. and Venables, Anthony J. (1999). "Foreign direct investment as a catalyst for industrial development", European Economic Review, Elsevier, vol. 43(2). pages 335-356.

Markusen, J.R. (2002). Multinational firms and the Theory of International Trade, Cambridge, Mass. MIT Press.

Nordal K.B (2001) "Country risk, Country risk indices and valuation of FDI: a real options approach, Emerging Markets review 2, 1997-217. 
Singh, H. and Jung, K.W (1995). "Some new evidence on Determinants on Foreign Direct Investment in Developing Countries", Policy Research Working Paper 1531, the World Bank.

Schneider, F., and Frey B. (1985). "Economic and Political Determinants of Foreign Direct Investment." World Development. 13 (2): 161-175.

\section{Appendix}

\section{List of countries}

Albania, Algeria, Argentina, Armenia, Azerbaijan, Belarus, Brazil, Bulgaria, Chile, China, Colombia, Croatia, Cyprus, Czech Republic, Ecuador, Egypt, Estonia, Greece, Hong Kong China, Hungary, India, Latvia, Lithuania, Poland, Romania, Russian Federation, Serbia, Slovak Republic, Slovenia, Tunisia, Turkey, Ukraine, Vietnam.

Table 1. Variables and sources of data

\begin{tabular}{cc} 
Variable & Source \\
\hline \hline FDI in of GDP & World Bank (2010) \\
GDP & World Bank (2010) \\
Growth in GDP & World Bank (2010) \\
Population & World Bank (2010) \\
Trade (imports+exports) as \% of GDP & World Bank (2010) \\
Inflation & World Bank (2010) \\
Unit labor costs & International Labour Organization (2009) \\
Public expenditure as \% of GDP & ILO and INS (2009) \\
Infrastructure & IFS (2010) \\
Real exchange rate & World Bank (2010) \\
Business Climate & IFS (2010) \\
Political risks & World Bank (2010) \\
\hline
\end{tabular}


Table 2. Estimations results: FDI and business climate (1996-2008)

\begin{tabular}{|c|c|c|c|c|c|c|}
\hline \multirow[t]{2}{*}{ Independent Variables } & & \multicolumn{5}{|c|}{ Dependent Variable: Ln FDI in \% GDP } \\
\hline & $(1)$ & $(2)$ & (3) & $(4)$ & $(5)$ & (6) \\
\hline constante & $\begin{array}{c}-17,45^{* * *} \\
(1,74)\end{array}$ & $\begin{array}{c}-17,94 * * * \\
(1,74)\end{array}$ & $\begin{array}{c}-17,58^{* * *} \\
(1,94)\end{array}$ & $\begin{array}{c}-17,29 * * * \\
(1,74)\end{array}$ & $\begin{array}{c}-17,50 * * * \\
(1,77)\end{array}$ & $\begin{array}{c}-18,10 * * * \\
(1,76)\end{array}$ \\
\hline Political risk & - & $\begin{array}{c}0,21 * * \\
(0,09)\end{array}$ & $\begin{array}{l}0,21 * * \\
(0,09)\end{array}$ & $\begin{array}{l}0,19 * * \\
(0,09)\end{array}$ & $\begin{array}{c}0,19 * * \\
(0,09)\end{array}$ & $\begin{array}{l}0,21 * * \\
(0,10)\end{array}$ \\
\hline Ln GNI/cap & $\begin{array}{c}0,15 \\
(0,13)\end{array}$ & $\begin{array}{c}0,22 \\
(0,14)\end{array}$ & $\begin{array}{c}0,22 \\
(0,14)\end{array}$ & $\begin{array}{l}0,29 * * \\
(0,14)\end{array}$ & $\begin{array}{l}0,30 * * \\
(0,14)\end{array}$ & $\begin{array}{l}0,26^{*} \\
(0,15)\end{array}$ \\
\hline ln_Growth & $\begin{array}{l}-0,003 \\
(0,03)\end{array}$ & $\begin{array}{l}-0,002 \\
(0,03)\end{array}$ & $\begin{array}{l}-0,004 \\
(0,03)\end{array}$ & $\begin{array}{l}-0,03 \\
(0,03)\end{array}$ & $\begin{array}{l}-0,03 \\
(0,03)\end{array}$ & $\begin{array}{l}-0,003 \\
(0,03)\end{array}$ \\
\hline Ln Trade & $\begin{array}{c}4,37 * * * \\
(0,38)\end{array}$ & $\begin{array}{c}4,43 * * * \\
(0,38)\end{array}$ & $\begin{array}{c}4,45^{* * * *} \\
(0,39)\end{array}$ & $\begin{array}{c}4,48^{* * * *} \\
(0,38)\end{array}$ & $\begin{array}{c}4,46 * * * \\
(0,38)\end{array}$ & $\begin{array}{c}4,45^{* * *} \\
(0,39)\end{array}$ \\
\hline Ln Inflation & $\begin{array}{c}-0,07 * * \\
(0,03)\end{array}$ & $\begin{array}{l}-0,06^{*} \\
(0,03)\end{array}$ & $\begin{array}{c}-0,06^{*} \\
(0,03)\end{array}$ & $\begin{array}{c}-0,07^{* *} \\
(0,03)\end{array}$ & $\begin{array}{c}-0,07^{* *} \\
(0,03)\end{array}$ & $\begin{array}{l}-0,06^{*} \\
(0,03)\end{array}$ \\
\hline Ln_roads & - & - & $\begin{array}{l}-0,11 \\
(0,26)\end{array}$ & - & - & - \\
\hline Ln Public Expenditures & - & - & - & $\begin{array}{c}0,11 * * * \\
(0,04)\end{array}$ & $\begin{array}{c}0,10^{* * *} \\
(0,04)\end{array}$ & - \\
\hline Ln RER & - & - & - & - & $\begin{array}{c}0,10 \\
(0,14)\end{array}$ & - \\
\hline Ln_Unit labor costs & - & - & - & - & - & $\begin{array}{c}0,10 \\
(0,15)\end{array}$ \\
\hline R2 Within & 0,29 & 0,30 & 0,30 & 0,32 & 0,32 & 0,30 \\
\hline R2 Between & 0,32 & 0,33 & 0,34 & 0,35 & 0,36 & 0,33 \\
\hline $\mathrm{R} 2$ overall & 0,24 & 0,25 & 0,26 & 0,27 & 0,27 & 0,25 \\
\hline $\mathrm{Nb}$. d'observations & 429 & 429 & 429 & 429 & 429 & 429 \\
\hline $\mathrm{Nb}$. groupes & 33 & 33 & 33 & 33 & 33 & 33 \\
\hline $\begin{array}{l}\text { Hausman test } \\
(\text { Prob }>\text { Chi2) }\end{array}$ & $\begin{array}{l}40,72 \\
(0,00)\end{array}$ & $\begin{array}{l}39,91 \\
(0,00)\end{array}$ & $\begin{array}{l}32,52 \\
(0,00)\end{array}$ & $\begin{array}{l}32,42 \\
(0,00)\end{array}$ & $\begin{array}{l}30,92 \\
(0,00)\end{array}$ & $\begin{array}{l}38,90 \\
(0,00)\end{array}$ \\
\hline $\begin{array}{l}\text { Breusch-Pagan test } \\
\text { (Prob }>\text { Chi } 2 \text { ) }\end{array}$ & $\begin{array}{c}326,23 \\
(0.00)\end{array}$ & $\begin{array}{c}322,62 \\
(0.00)\end{array}$ & $\begin{array}{c}293,87 \\
(0.00)\end{array}$ & $\begin{array}{c}307,12 \\
(0.00)\end{array}$ & $\begin{array}{l}310,05 \\
(0.00)\end{array}$ & $\begin{array}{l}320,63 \\
(0.00)\end{array}$ \\
\hline
\end{tabular}

Note: Robust standard errors in parentheses; * - Significant at the 10\% level; $\quad * *$ - Significant at the 5\% level; *** - Significant at the $1 \%$ level. 
Table 3. Estimations results: FDI and political risk (1996-2008)

\begin{tabular}{|c|c|c|c|c|c|c|c|}
\hline Independent Variables & \multicolumn{7}{|c|}{ Dependent Variable: Ln FDI in \% GDP } \\
\hline & $(1)$ & $(2)$ & $(3)$ & (4) & $(5)$ & $(6)$ & (7) \\
\hline constante & $\begin{array}{c}-17,46^{* * *} \\
(1,74)\end{array}$ & $\begin{array}{c}-16,59 * * * \\
(1,92)\end{array}$ & $\begin{array}{c}-16,26^{* * *} \\
(2,09)\end{array}$ & \begin{tabular}{|c|}
$-16,12 * * *$ \\
$(1,90)$
\end{tabular} & \begin{tabular}{|c|}
$-16,23 * * *$ \\
$(1,91)$
\end{tabular} & \begin{tabular}{|c|}
$-16,63 * * *$ \\
$(1,92)$
\end{tabular} & $\begin{array}{c}-16,59 * * * \\
(1,91)\end{array}$ \\
\hline Business climate & - & $\begin{array}{l}0,23 \\
(0,21)\end{array}$ & $\begin{array}{l}0,22 \\
(0,21)\end{array}$ & $\begin{array}{l}0,19 \\
(0,21)\end{array}$ & $\begin{array}{l}0,21 \\
(0,21)\end{array}$ & $\begin{array}{l}0,24 \\
(0,22)\end{array}$ & $\begin{array}{l}0,18 \\
(0,21)\end{array}$ \\
\hline Ln GNI/cap & $\begin{array}{c}0,15 \\
(0,13)\end{array}$ & $\begin{array}{l}0,22 \\
(0,16)\end{array}$ & $\begin{array}{l}0,22 \\
(0,15)\end{array}$ & $\begin{array}{c}0,29 * * \\
(0,15)\end{array}$ & $\begin{array}{c}0,31 * * \\
(0,15)\end{array}$ & $\begin{array}{l}0,25 \\
(0,17)\end{array}$ & $\begin{array}{c}0,35 * * \\
(0,15)\end{array}$ \\
\hline Growth & $\begin{array}{c}-0,003 \\
(0,03)\end{array}$ & $\begin{array}{c}-0,005 \\
(0,03)\end{array}$ & $\begin{array}{l}-0,007 \\
(0,03)\end{array}$ & $\begin{array}{l}-0,03 \\
(0,03)\end{array}$ & $\begin{array}{l}-0,03 \\
(0,03)\end{array}$ & $\begin{array}{c}-0,006 \\
(0,03)\end{array}$ & $\begin{array}{l}-0,03 \\
(0,03)\end{array}$ \\
\hline Ln Trade & $\begin{array}{c}4,37 * * * \\
(0,38)\end{array}$ & $\begin{array}{c}4,35^{* * *} \\
(0,39)\end{array}$ & $\begin{array}{c}4,37 * * * \\
(0,39)\end{array}$ & $\begin{array}{c}4,41^{* * * *} \\
(0,38)\end{array}$ & $\begin{array}{c}4,39 * * * \\
(0,38)\end{array}$ & $\begin{array}{c}4,36 * * * \\
(0,39)\end{array}$ & $\begin{array}{c}4,46 * * * \\
(0,38)\end{array}$ \\
\hline Ln Inflation & $\begin{array}{c}-0,07 * * \\
(0,03)\end{array}$ & $\begin{array}{c}-0,07 * * \\
(0,03)\end{array}$ & $\begin{array}{c}-0,07 * * \\
(0,03)\end{array}$ & $\begin{array}{c}-0,08 * * \\
(0,03)\end{array}$ & $\begin{array}{c}0,08 * * \\
(0,03)\end{array}$ & $\begin{array}{c}-0,07 * * \\
(0,03)\end{array}$ & $\begin{array}{c}-0,07 * * \\
(0,03)\end{array}$ \\
\hline Ln_roads & - & - & $\begin{array}{l}-0,11 \\
(0,26)\end{array}$ & - & - & - & - \\
\hline Ln Public Expenditures & - & & - & $\begin{array}{c}0,11 * * * \\
(0,04)\end{array}$ & $\begin{array}{c}0,11 * * * \\
(0,04)\end{array}$ & - & $\begin{array}{c}0,10 * * * \\
(0,04)\end{array}$ \\
\hline Ln RER & - & & - & - & $\begin{array}{l}0,10 \\
(0,14)\end{array}$ & - & - \\
\hline Ln_Unit labor costs & - & & - & - & - & $\begin{array}{l}0,07 \\
(0,15)\end{array}$ & - \\
\hline Ln_Political Risk & - & & - & - & & - & $\begin{array}{c}0,19 * * \\
(0,10)\end{array}$ \\
\hline R2 Within & $\overline{0,29}$ & 0,30 & 0,30 & 0,31 & 0,31 & $\overline{0,30}$ & 0,32 \\
\hline R2 Between & 0,32 & 0,33 & 0,34 & 0,36 & 0,36 & 0,33 & 0,36 \\
\hline $\mathrm{R} 2$ overall & 0,24 & 0,25 & 0,26 & 0,27 & 0,27 & 0,25 & 0,27 \\
\hline $\mathrm{Nb}$. d'observations & 429 & 429 & 429 & 429 & 429 & 429 & 429 \\
\hline $\mathrm{Nb}$. groupes & 33 & 33 & 33 & 33 & 33 & 33 & 33 \\
\hline Hausman test & 40,72 & 37,41 & 32,25 & 32,31 & 28,97 & 36,59 & 32,05 \\
\hline $\begin{array}{l}(\text { Prob }>\text { Ch12 }) \\
\text { Breusch-Pagan test }\end{array}$ & $\begin{array}{c}(0,00) \\
326,23\end{array}$ & $\begin{array}{c}(0,00) \\
294,62\end{array}$ & $\begin{array}{c}(0,00) \\
273,41\end{array}$ & $\begin{array}{c}(0,00) \\
280,71\end{array}$ & $\begin{array}{c}(0,00) \\
285,67\end{array}$ & $\begin{array}{c}(0,00) \\
294,60\end{array}$ & $\begin{array}{c}(0,00) \\
282,84\end{array}$ \\
\hline$($ Prob $>$ Chi2) & $(0.00)$ & $(0.00)$ & $(0.00)$ & $(0.00)$ & $(0.00)$ & $(0.00)$ & $(0.00)$ \\
\hline
\end{tabular}

Note: Robust standard errors in parentheses; * - Significant at the $10 \%$ level; ** - Significant at the $5 \%$ level; *** - Significant at the $1 \%$ level. 
Table 4. Estimations results: FDI and business climate (1996-2008)

\begin{tabular}{|c|c|c|c|c|c|c|}
\hline \multirow[t]{2}{*}{ Independent Variables } & & \multicolumn{5}{|c|}{ Dependent Variable: Ln FDI in \% GDP } \\
\hline & $(1)$ & $(2)$ & (3) & $(4)$ & $(5)$ & $(6)$ \\
\hline constante & $\begin{array}{c}0,11 * * * \\
(0,03)\end{array}$ & $\begin{array}{c}0,11 * * * \\
(0,03)\end{array}$ & $\begin{array}{c}0,14 * * * \\
(0,04)\end{array}$ & $\begin{array}{c}0,12 * * * \\
(0,03)\end{array}$ & $\begin{array}{c}0,15 * * * \\
(0,03)\end{array}$ & $\begin{array}{c}0,11 * * * \\
(0,03)\end{array}$ \\
\hline Political risk & - & $\begin{array}{c}0,03 \\
(0,07)\end{array}$ & $\begin{array}{l}-0,11 \\
(0,11)\end{array}$ & $\begin{array}{l}-0,04 \\
(0,08)\end{array}$ & $\begin{array}{l}-0,05 \\
(0,08)\end{array}$ & $\begin{array}{l}-0,03 \\
(0,08)\end{array}$ \\
\hline $\ln \mathrm{FDI}(-1)$ & $\begin{array}{c}0,42 * * * \\
(0,03)\end{array}$ & $\begin{array}{c}0,42 * * * \\
(0,03)\end{array}$ & $\begin{array}{c}0,44 * * * \\
(0,03)\end{array}$ & $\begin{array}{c}0,43^{* * *} \\
(0,03)\end{array}$ & $\begin{array}{c}0,41 * * * \\
(0,03)\end{array}$ & $\begin{array}{c}0,44 * * * \\
(0,04)\end{array}$ \\
\hline Ln GNI/cap & $\begin{array}{c}1,75 * * * \\
(0,49)\end{array}$ & $\begin{array}{c}1,89 * * * \\
(0,37)\end{array}$ & $\begin{array}{c}2,12 * * * \\
(0,50)\end{array}$ & $\begin{array}{c}1,96 * * * \\
(0,41)\end{array}$ & $\begin{array}{c}2,05 * * * \\
(0,41)\end{array}$ & $\begin{array}{c}1,99 * * * \\
(0,51)\end{array}$ \\
\hline Growth & $\begin{array}{c}0,12 \\
(0,01)\end{array}$ & $\begin{array}{c}0,02 \\
(0,01)\end{array}$ & $\begin{array}{l}0,01 \\
(0,02)\end{array}$ & $\begin{array}{l}0,02 \\
(0,02)\end{array}$ & $\begin{array}{l}-0,01 \\
(0,02)\end{array}$ & $\begin{array}{l}0,02 \\
(0,02)\end{array}$ \\
\hline Ln Trade & $\begin{array}{c}2,77 * * * \\
(0,37)\end{array}$ & $\begin{array}{c}2,60 * * * \\
(0,49)\end{array}$ & $\begin{array}{c}2,07 * * * \\
(0,73)\end{array}$ & $\begin{array}{c}2,49 * * * \\
(0,43)\end{array}$ & $\begin{array}{c}1,99 * * * \\
(0,61)\end{array}$ & $\begin{array}{c}2,58 * * * \\
(0,55)\end{array}$ \\
\hline Ln Inflation & $\begin{array}{c}0,03 \\
(0,01)\end{array}$ & $\begin{array}{c}0,04 \\
(0,01)\end{array}$ & $\begin{array}{c}0,04 * * * \\
(0,01)\end{array}$ & $\begin{array}{l}0,03^{*} \\
(0,02)\end{array}$ & $\begin{array}{l}0,03^{*} \\
(0,02)\end{array}$ & $\begin{array}{c}0,03 * * \\
(0,01)\end{array}$ \\
\hline Ln_roads & - & - & $\begin{array}{l}-0,36 \\
(1,12)\end{array}$ & - & - & - \\
\hline Ln Public Expenditures & - & - & - & $\begin{array}{c}0,05 * * \\
(0,03)\end{array}$ & $\begin{array}{c}0,08 * * * \\
(0,03)\end{array}$ & - \\
\hline Ln RER & - & - & - & - & $\begin{array}{c}-0,54 * * * \\
(0,18)\end{array}$ & - \\
\hline Ln_Unit labor costs & - & - & - & - & - & $\begin{array}{c}0,35 * * \\
(0,16)\end{array}$ \\
\hline Nb. d'observations & 363 & 363 & 363 & 363 & 363 & 363 \\
\hline $\mathrm{Nb}$. groupes & 33 & 33 & 33 & 33 & 33 & 33 \\
\hline Wald $X_{2}$ (5) test & 773,48 & 772,16 & 1296,88 & 798,15 & 1749,53 & 872,62 \\
\hline Sargan test $-X 2(67)$ & 32,23 & 32,07 & 30,10 & 29,85 & 31,06 & 30,08 \\
\hline $\begin{array}{c}\mathrm{AB}(2) \text { test } \mathrm{H} 0=0 \\
\text { (z-value) }\end{array}$ & 0,15 & 0,15 & 0,18 & 0,15 & 0,20 & 0,15 \\
\hline
\end{tabular}

Note: Robust standard errors in parentheses; * - Significant at the 10\% level; ** - Significant at the 5\% level; *** - Significant at the $1 \%$ level. 
Table 5. Estimations results: FDI and political risk (1996-2008)

\begin{tabular}{|c|c|c|c|c|c|c|c|}
\hline \multirow[t]{2}{*}{ Independent Variables } & \multicolumn{7}{|c|}{ Dependent Variable: Ln FDI in \% GDP } \\
\hline & $(1)$ & $(2)$ & $(3)$ & (4) & $(5)$ & $(6)$ & $(7)$ \\
\hline constante & $\begin{array}{c}0,11 * * * \\
(0,03)\end{array}$ & $\begin{array}{c}0,10 * * * \\
(0,03)\end{array}$ & $(0,04)$ & $\begin{array}{c}0,09 * * * \\
(0,04)\end{array}$ & $\begin{array}{c}0,13 * * * \\
(0,03)\end{array}$ & $\begin{array}{c}0,12 * * * \\
(0,03)\end{array}$ & $\begin{array}{c}0,12 * * * \\
(0,03)\end{array}$ \\
\hline Business climate & - & $\begin{array}{c}0,40 * * \\
(0,20)\end{array}$ & $\begin{array}{c}0,42 * * \\
(0,20)\end{array}$ & $\begin{array}{l}0,40 * \\
(0,23)\end{array}$ & $\begin{array}{l}0,30 \\
(0,19)\end{array}$ & $\begin{array}{c}0,42 * * \\
(0,22)\end{array}$ & $\begin{array}{l}0,43 * \\
(0,25)\end{array}$ \\
\hline $\ln \mathrm{FDI}(-1)$ & $\begin{array}{c}0,42 \\
(0,03)\end{array}$ & $\begin{array}{c}0,43 * * * \\
(0,03)\end{array}$ & $\begin{array}{c}0,40 * * * \\
(0,04)\end{array}$ & $\begin{array}{c}0,42 * * * \\
(0,04)\end{array}$ & $\begin{array}{c}0,41 * * * \\
(0,03)\end{array}$ & $\begin{array}{c}0,43 * * * \\
(0,04)\end{array}$ & $\begin{array}{c}0,43 * * * \\
(0,03)\end{array}$ \\
\hline Ln GNI/cap & $\begin{array}{c}1,75 * * * \\
(0,49)\end{array}$ & $\begin{array}{c}1,65 * * * \\
(0,46)\end{array}$ & $\begin{array}{c}1,98 * * \\
(1,03)\end{array}$ & $\begin{array}{c}1,74 * * * \\
(0,48)\end{array}$ & $\begin{array}{c}2,03 * * * \\
(0,41)\end{array}$ & $\begin{array}{c}2,07 * * * \\
(0,41)\end{array}$ & $\begin{array}{c}2,17 * * * \\
(0,43)\end{array}$ \\
\hline Growth & $\begin{array}{c}0,01 \\
(0,01)\end{array}$ & $\begin{array}{c}0,01 \\
(0,01)\end{array}$ & $\begin{array}{c}0,01 \\
(0,01)\end{array}$ & $\begin{array}{c}0,01 \\
(0,01)\end{array}$ & $\begin{array}{l}0,02 \\
(0,02)\end{array}$ & $\begin{array}{l}-0,01 \\
(0,02)\end{array}$ & $\begin{array}{l}0,01 \\
(0,02)\end{array}$ \\
\hline Ln Trade & $\begin{array}{c}2,77 * * * \\
(0,37)\end{array}$ & $\begin{array}{c}2,12 * * * \\
(0,44)\end{array}$ & $\begin{array}{c}2,29 * * * \\
(0,46)\end{array}$ & $\begin{array}{c}2,36 * * * \\
(0,45)\end{array}$ & $\begin{array}{c}2,16 * * * \\
(0,53)\end{array}$ & $\begin{array}{c}1,81 * * * \\
(0,67)\end{array}$ & $\begin{array}{c}2,26 * * * \\
(0,45)\end{array}$ \\
\hline Ln Inflation & $\begin{array}{c}0,03 * * \\
(0,01)\end{array}$ & $\begin{array}{c}0,03 * * * \\
(0,01)\end{array}$ & $\begin{array}{c}0,04 * * * \\
(0,01)\end{array}$ & $\begin{array}{l}0,02 \\
(0,02)\end{array}$ & $\begin{array}{l}0,03 * \\
(0,01)\end{array}$ & $\begin{array}{c}0,03 * * \\
(0,01)\end{array}$ & $\begin{array}{l}0,03 * \\
(0,02)\end{array}$ \\
\hline Ln_roads & - & - & $\begin{array}{l}-0,28 \\
(0,76)\end{array}$ & - & - & - & - \\
\hline Ln Public Expenditures & - & - & - & $\begin{array}{l}0,05 * \\
(0,03)\end{array}$ & $\begin{array}{l}0,05 * \\
(0,03)\end{array}$ & - & $\begin{array}{c}0,07 * * \\
(0,03)\end{array}$ \\
\hline Ln RER & - & - & - & - & $\begin{array}{l}-0,57 \\
(0,46)\end{array}$ & - & - \\
\hline Ln_Unit labor costs & - & - & - & - & - & $\begin{array}{c}0,26 * * \\
(0,13)\end{array}$ & - \\
\hline Ln_Political Risk & - & - & - & - & - & - & $\begin{array}{c}0,03 \\
(0,09)\end{array}$ \\
\hline Nb. d'observations & 363 & 363 & 363 & 363 & 363 & 363 & 363 \\
\hline $\mathrm{Nb}$. groupes & 33 & 33 & 33 & 33 & 33 & 33 & 33 \\
\hline Wald $X_{2}$ (6) test & 773,48 & 445,33 & 472,80 & 446,26 & 880,83 & 770,5 & 805,32 \\
\hline Sargan test $-X 2(66)$ & 32,23 & 28,36 & 27,40 & 27,69 & 26,84 & 24,38 & 27,67 \\
\hline $\mathrm{AB}(2)$ test $\mathrm{H} 0=0$ & 0,15 & 0,15 & 0,17 & 0,14 & 0,15 & 0,17 & 0,14 \\
\hline (z-value) & 1,45 & 1,45 & 1,38 & 1,48 & 1,44 & 1,37 & 1,47 \\
\hline
\end{tabular}

Note: Robust standard errors in parentheses; * - Significant at the 10\% level; ** - Significant at the 5\% level; *** - Significant at the $1 \%$ level. 